\title{
Do Community College Presidents and Government Officials Share the Same Perspective?
}

\author{
GAIL VALLANCE BARRINGTON*
}

\begin{abstract}
A three-round policy Delphi explored the opinions of Alberta community college presidents and senior officials of Alberta Advanced Education and Manpower regarding the impact of environmental forces as defined by Hall's typology on the development of community colleges in the eighties. Overall, the two groups shared a similar perspective on the environment, as disagreement surfaced on only two major environmental forces. The forces eliciting disagreement were Government Priorities Among All Sectors and A Growing Alberta Population.
\end{abstract}

\section{RESUME}

La technique Delphi fut utilisée à trois reprises pour connaître la similitude d'opinions entre les présidents des collèges communautaires de l'Alberta et les autorités gouvernementales du Département de la Main-d'oeuvre et de l'Education supérieure au sujet de l'impact des forces environnantes telles que définies par la typologie de Hall, sur le développement des collèges communautaires dans les années 1980. Dans l'ensemble, les deux groupes partagèrent les mêmes vues sur l'environnement à l'exception des deux variables suivantes: les priorités gouvernementales entre les divers secteurs et la croissance de la population de l'Alberta.

A recent study at the University of Alberta, in the form of a three-round policy Delphi, explored the opinions of Alberta community college presidents and senior officials of Alberta Advanced Education and Manpower regarding the impact of the environment on the development of community colleges in the eighties.

* Formerly employed at Grant MacEwan Community College. 
The focus of the study moved from a highly generalized view of the community college environment in the form of Hall's typology of general environmental conditions (technological, legal, political, economic, demographic, ecological, and cultural factors) to particular actions colleges might take in response to environmental influences on a specific policy decision area.

The panel of experts selected to participate in the study was comprised of two sub-panels. The first was made up of the ten community college presidents in the Alberta public system. The second consisted of seven senior officials of Alberta Advanced Education and Manpower, ranging from the Deputy Ministerial to the Directorship level, all with responsibilities in the area of community college education.

\section{CHARACTERISTICS OF THE PRESIDENTS}

The community college presidents were selected for their Janus-like position as boundry spanners - looking both inward to their institutions, and outward to the environment of their colleges, rather than for any authority or decisionmaking power. As Cohen and March (1974) so clearly pointed out in their study of American college presidents, "The presidency is an illusion" (p.2) and the college is "a prototypic organized anarchy" (p.3). They claimed that although presidents believe in comprehensive planning, they do not do it because longrange plans presume clarity of goals, an understanding of technology, and continuity of leadership (p.114). Colleges and universities have none of these and planning is generally restricted to capital, physical, and fiscal areas. However, Cohen and March claimed that long-term plans could serve other purposes, such as symbols, advertisements, games, and excuses for interaction (pp. 114-115). These "political" motives are valid and in themselves could yield positive results but the educative process involved through participation in this Delphi study might very well be beneficial too. The experience of viewing policy analysis from an environmental perspective and the data thus generated could provide useful input to future college-based policy decisions.

A glance at the profile of the college presidents provided in Table 1 reveals that their mean age was 49 (a range of 39 to 60 ) and the mean number of years they had been in their present position was 4.8 (a range of two and a half months to fourteen years), with a mean total number of years in postsecondary education of 15.3 (a range of 1 to 25 years). Their educational qualifications ranged from Bachelor to Doctorate. Only three presidents indicated that their specialization was Educational Administration; the rest divided between humanities and physical sciences backgrounds.

\section{CHARACTERISTICS OF ALBERTA GOVERNMENT OFFICIALS}

The senior officials at Alberta Advanced Education and Manpower were selected to provide dialogue in the policy Delphi in an attempt to identify opposing views regarding the identification and influence of major environmental forces, should 
Table 1

Profile of Panel Members

\begin{tabular}{|c|c|c|c|c|c|c|c|c|c|c|c|c|}
\hline \multirow[b]{2}{*}{ Sub-Pane 1} & \multicolumn{2}{|c|}{ Sex } & \multicolumn{2}{|c|}{ Age } & \multirow{2}{*}{$\begin{array}{l}\text { Highest } \\
\text { Bachelor }\end{array}$} & \multicolumn{3}{|c|}{ Educational Qualification } & \multicolumn{2}{|c|}{$\begin{array}{l}\text { Years in } \\
\text { Present } \\
\text { Position }\end{array}$} & \multicolumn{2}{|c|}{$\begin{array}{l}\text { Years in } \\
\text { Postsecondary } \\
\text { Educat ion }\end{array}$} \\
\hline & M & $\mathbf{F}$ & Mean & S.D. & & Masters & Doctorate & Other & Mean & S.D. & Mean & S.D. \\
\hline $\begin{array}{l}\text { Group I } \\
\text { College } \\
\text { Presidents } \\
(\mathrm{N}=10)\end{array}$ & 10 & 0 & 49 & 6.8 & 5 & 1 & 4 & 0 & 4.9 & 5.1 & 15.3 & 7.6 \\
\hline $\begin{array}{l}\text { Group } 2 \\
\text { Government } \\
\text { Officials } \\
(\mathrm{N}=7)\end{array}$ & 6 & 1 & $43^{1}$ & 6.6 & 0 & 0 & 6 & $1^{2}$ & 3.7 & 2.2 & 11.3 & 3.4 \\
\hline
\end{tabular}

' For age category, $N=6$.

${ }^{2}$ other qualification was a C.A. 
any exist. College representatives and government officials frequently appear to debate issues due to differing perspectives and it was thought that the study might identify some major areas of disagreement.

The profile of government officials in Table 1 shows that their mean age was 43 (a range of 34 to 50 ), and the mean number of years in their present position was 3.7 (a range of 1 to 7 years), with a total number of years in postsecondary education of 11.3 (a range of 8 to 17 years). Their educational qualifications were grouped at the doctorate level, all but one in the area of Educational Administration. One member's highest qualification was that of Chartered Accountant.

In summary, a comparison of the two sub-panels shows that college presidents were older, had less education with less of it in Educational Adminstration, had been in their present positions longer, and had more years of experience in postsecondary education. On the other hand, the government officials were younger, had more education, mainly in the field of Educational Administration, had been in their present position a shorter period of time, and had fewer years experience in postsecondary education, although it was still a substantial number.

\section{MAJOR ENVIRONMENTAL FORCES IDENTIFIED}

One hundred and two environmental forces were identified by panelists in Round $I$ of the study as influencing the direction of future policy-making in Alberta's community colleges. From this list, 16 forces were rated as having a major influence in the next decade. These included, in rank order:

1. The Demand for Technological Training and Retraining

2. A Growing Alberta Population

3. Intensified Development of the Resource Industry

4. Inflation

Industry as a Pressure Group

Increasing In-migration

5. Buoyant Economy

Decentralization of College Services by Region

Regional Expansion of the Population

6. Faculty as a Pressure Group

A Government Policy of Fiscal Restraint

Industrial Expansion

Computer Technology

7. Growth in the Service Sector

8. Government Priorities Among All Sectors

A Different Student Population.

\section{GROUP DIFFERENCES}

The Round II questionnaire asked panelists to rate each environmental force on two four-point scales: Likelihood of Occurence in the Next Decade; and Degree of Impact on Alberta's Community College System. 
Through the use of the t-test, significant differences at the .05 level were identified in only $5.9 \%$ of questionnaire items for either Likelihood, Impact, or both. (A detailed analysis of the results of the t-test is available in Table 2.) The result of the t-test approaches the null hypothesis, revealing only a minimal difference beyond what could be attributed to chance. The similarity between the two sub-panels is highlighted by this finding; however, the slight discrepancy which does occur warrants further investigation. The items of disagreement between the two groups are ordered by significance (percentage of respondents who rated Likelihood and Impact as either 1, Very Likely, High Impact, or 2, Likely, Moderate Impact) in Table 3.

The single item of this list to occur on the final list of 16 Major Environmental Forces identified in Round II was Government Priorities Among all Sectors. This environmental force was rated as significant or at least likely to occur and at least have a moderate impact on the future direction of the colleges by $82.35 \%$ of all panelists. Among the reasons for importance cited by individuals in support of the choice of this force were the following: (1) Limitation of public support for postsecondary education; (2) The demand for greater accountability from the colleges; (3) The impetus for colleges to seek funding elsewhere; (4) The determination of the regional expansion rate; and (5) The dependence on government grants at the expense of college autonomy.

However, college presidents believed that the force of Government Priorities Among All Sectors was more likely to occur (mean = 1.3) while Advanced Education and Manpower officials felt it was less likely to occur (mean $=2.0$ ). College presidents felt that the impact of this force would be quite high (mean $=1.4$ ) although there was less agreement among them (S.D. $=0.5$ ) while Advanced Education and Manpower officials believed that the impact would be only moderate (mean $=2.1$ ) and agreed more about this view $($ S.D. $=0.4$ ). While both groups considered Government Priorities Among All Sectors to be a major environmental force, college presidents considered it more significant than did government officials.

The remainder of the items of disagreement between the two sub-panels fell below the $89 \%$ criterion for the identification of significant environmental forces. However, a brief look at group differences is instructive.

The force, Government Priorities within the Area of Education, was rated as significant by $76.47 \%$ of all panelists. Again, this force was deemed more likely to occur by college presidents (mean $=1.4$ ) with greater impact (mean $=1.4$ ), while government officials felt that the force was only moderately likely to occur (mean $=2.1$ ) with only moderate impact (mean $=2.3$ ). The presidents demonstrated much more agreement on their opinion (S.D. $=0.5$ in both cases) than did the Advanced Education and Manpower officials (Likelihood S.D. $=0.9$, Impact S.D. $=1.0$ ).

It appears that the area of government priorities, both generally and within the field of education, was viewed differently by the two sub-panels. Presidents believed that the forces were more significant in their impact on college development; governmen: officials felt they were less significant. 
Table 2

Items of Significant Difference, Identified by the $t-T e s t$ for Groups $1^{1}$ and $2^{2}$, Round 11

\begin{tabular}{|c|c|c|c|c|c|c|}
\hline Environmental Force & $\begin{array}{l}\text { Rating } \\
\text { Scale }\end{array}$ & Group & $\begin{array}{l}\text { Number of } \\
\text { Respondents }\end{array}$ & Mean & SD & $\begin{array}{c}\text { Pooled Variance } \\
\text { Estimate } \\
\text { 2-Tail } \\
\text { Probability }\end{array}$ \\
\hline \multirow[t]{2}{*}{$\begin{array}{l}\text { Government Priorities Among } \\
\text { All Sectors }\end{array}$} & $L^{3}$ & $\begin{array}{l}1 \\
2\end{array}$ & $\begin{array}{l}9 \\
7\end{array}$ & $\begin{array}{l}1.3 \\
2.0\end{array}$ & $\begin{array}{l}0.5 \\
0.6\end{array}$ & 0.027 \\
\hline & $1^{4}$ & $\begin{array}{l}1 \\
2\end{array}$ & $\begin{array}{l}9 \\
7\end{array}$ & $\begin{array}{l}1.4 \\
2.1\end{array}$ & $\begin{array}{l}0.5 \\
0.4\end{array}$ & 0.010 \\
\hline \multirow[t]{2}{*}{$\begin{array}{l}\text { Government Priorities within } \\
\text { the Area of Education }\end{array}$} & $\mathrm{L}$ & $\begin{array}{l}1 \\
2\end{array}$ & $\begin{array}{r}10 \\
7\end{array}$ & $\begin{array}{l}1.4 \\
2.1\end{array}$ & $\begin{array}{l}0.5 \\
0.9\end{array}$ & 0.047 \\
\hline & 1 & $\begin{array}{l}1 \\
2\end{array}$ & $\begin{array}{r}10 \\
7\end{array}$ & $\begin{array}{l}1.4 \\
2.3\end{array}$ & $\begin{array}{l}0.5 \\
1.0\end{array}$ & 0.025 \\
\hline Urbanization & $L$ & $\begin{array}{l}1 \\
2\end{array}$ & $\begin{array}{r}10 \\
7\end{array}$ & $\begin{array}{l}1.4 \\
2.1\end{array}$ & $\begin{array}{l}0.5 \\
0.7\end{array}$ & 0.022 \\
\hline \multirow[t]{2}{*}{$\begin{array}{l}\text { Professions and 0ccupations } \\
\text { Legislation }\end{array}$} & $\mathrm{L}$ & $\begin{array}{l}1 \\
2\end{array}$ & $\begin{array}{r}10 \\
7\end{array}$ & $\begin{array}{l}2.3 \\
1.4\end{array}$ & $\begin{array}{l}0.7 \\
0.5\end{array}$ & 0.012 \\
\hline & 1 & $\begin{array}{l}1 \\
2\end{array}$ & $\begin{array}{r}10 \\
7\end{array}$ & $\begin{array}{l}2.6 \\
1.9\end{array}$ & $\begin{array}{l}0.7 \\
0.7\end{array}$ & 0.047 \\
\hline
\end{tabular}

IGroup $1=10$ Alberta community college presidents.

${ }^{2}$ Group $2=7$ Alberta Advanced Education and Manpower officials.

$3_{L}=$ Likelihood of Occurrence in the Next Decade.

${ }^{4} I=$ Degree of Impact on Alberta's Community College System. 
Table $2^{1,2}$ (continued)

\begin{tabular}{|c|c|c|c|c|c|c|}
\hline Environmental Force & $\begin{array}{l}\text { Rating } \\
\text { Scale }\end{array}$ & Group & $\begin{array}{l}\text { Number of } \\
\text { Respondents }\end{array}$ & Mean & SD & $\begin{array}{c}\text { Pooled Variance } \\
\text { Estimate } \\
2-T a i l \\
\text { Probability }\end{array}$ \\
\hline $\begin{array}{l}\text { Private Sector Funding } \\
\text { Increase }\end{array}$ & $1^{4}$ & $\begin{array}{l}1 \\
2\end{array}$ & $\begin{array}{r}10 \\
7\end{array}$ & $\begin{array}{l}2.7 \\
1.9\end{array}$ & $\begin{array}{l}0.8 \\
0.7\end{array}$ & 0.043 \\
\hline $\begin{array}{l}\text { Changes in Human Rights } \\
\text { Legislation }\end{array}$ & $L^{3}$ & $\begin{array}{l}1 \\
2\end{array}$ & $\begin{array}{r}10 \\
7\end{array}$ & $\begin{array}{l}1.9 \\
2.4\end{array}$ & $\begin{array}{l}0.3 \\
0.5\end{array}$ & 0.021 \\
\hline $\begin{array}{l}\text { Strained College-University } \\
\text { Relations }\end{array}$ & 1 & $\begin{array}{l}1 \\
2\end{array}$ & $\begin{array}{r}10 \\
7\end{array}$ & $\begin{array}{l}1.9 \\
2.7\end{array}$ & $\begin{array}{l}0.7 \\
0.5\end{array}$ & 0.022 \\
\hline $\begin{array}{l}\text { Questioning of Traditional } \\
\text { Values }\end{array}$ & $L$ & $\begin{array}{l}1 \\
2\end{array}$ & $\begin{array}{r}10 \\
7\end{array}$ & $\begin{array}{l}2.6 \\
1.9\end{array}$ & $\begin{array}{l}0.7 \\
0.7\end{array}$ & 0.047 \\
\hline $\begin{array}{l}\text { World-wide Economic } \\
\text { Depression }\end{array}$ & $L$ & $\begin{array}{l}1 \\
2\end{array}$ & $\begin{array}{r}10 \\
6\end{array}$ & $\begin{array}{l}2.1 \\
3.0\end{array}$ & $\begin{array}{l}0.7 \\
0.6\end{array}$ & 0.026 \\
\hline
\end{tabular}

IGroup $1=10$ Alberta community college presidents.

${ }^{2}$ Group $2=7$ Alberta Advanced Education and Manpower officials.

$3_{L}=$ Likelihood of Occurrence in the Next Decade.

$4_{1}=$ Degree of Impact on Alberta's Community College System. 
Items of Disagreement between Grougs $1^{1}$ and $2^{2}$, Round 11 by Significance 3

\begin{tabular}{|c|c|}
\hline Environmental Force & $\begin{array}{c}\text { Significance } \\
\text { Perceived by } \\
\text { Respondents } \\
(\%)\end{array}$ \\
\hline Government Priorities Among All Sectors & 82.35 \\
\hline Government Priorities within the Area of Education & 76.47 \\
\hline Urbanization & 76.47 \\
\hline Professional and Occupations Legislation & 64.71 \\
\hline Private Sector Funding Increase & 64.71 \\
\hline Changes in Human Rights Legislation & 58.52 \\
\hline Strained College-University Relations & 52.94 \\
\hline Questioning of Traditional Values & 41.18 \\
\hline World-wide Economic Depression & 35.29 \\
\hline $\begin{array}{l}1 \text { Group } 1=10 \text { Alberta community college presidents } \\
{ }^{2} \text { Group } 2=7 \text { Alberta Advanced Education and Manpow } \\
{ }^{3} \text { Significance = percentage of respondents who rate } \\
\text { Forces in Round } 11 \text { as either } 1 \text { or } 2 \text { for Likelihoo } \\
\text { the Next Decade ( } 1=\text { Very Likely, } 2 \text { = Likely) and } \\
\text { of Impact on Alberta's Community College System ( } \\
2 \text { = Moderate Impact). }\end{array}$ & $\begin{array}{l}\text { cials. } \\
\text { onmental } \\
\text { currence in } \\
\text { for Degree } \\
\text { h impact, }\end{array}$ \\
\hline
\end{tabular}

Other items of disagreement considered as more important forces by college presidents were (in decreasing order of significance): (1) Urbanization; (2) Changes in Human Rights Legislation; (3) Strained College-University Relations; and (4) A World-wide Economic Depression. Forces considered more important by government officials included: (1) Professions and Occupations Legislation; (2) Private Sector Funding Increase; and (3) Questioning of Traditional Values.

From the perspective of Hall's Typology (Table 4), it is interesting to note that Legislative and Political Forces were the most disputed (three items each), while there was only slight disagreement over Economic, Demographic, and Cultural/Societal Forces (one item each). No disagreement surfaced over either Technological or Ecological Forces.

In summary, then, group differences arising over the importance of certain environmental forces in Round II focused on Legislative and Political Forces. 
51 Do Community College Presidents and Government Officials Share the Same Perspective?

Table 4

Hall's Typology and Items of Disagreement

Round II

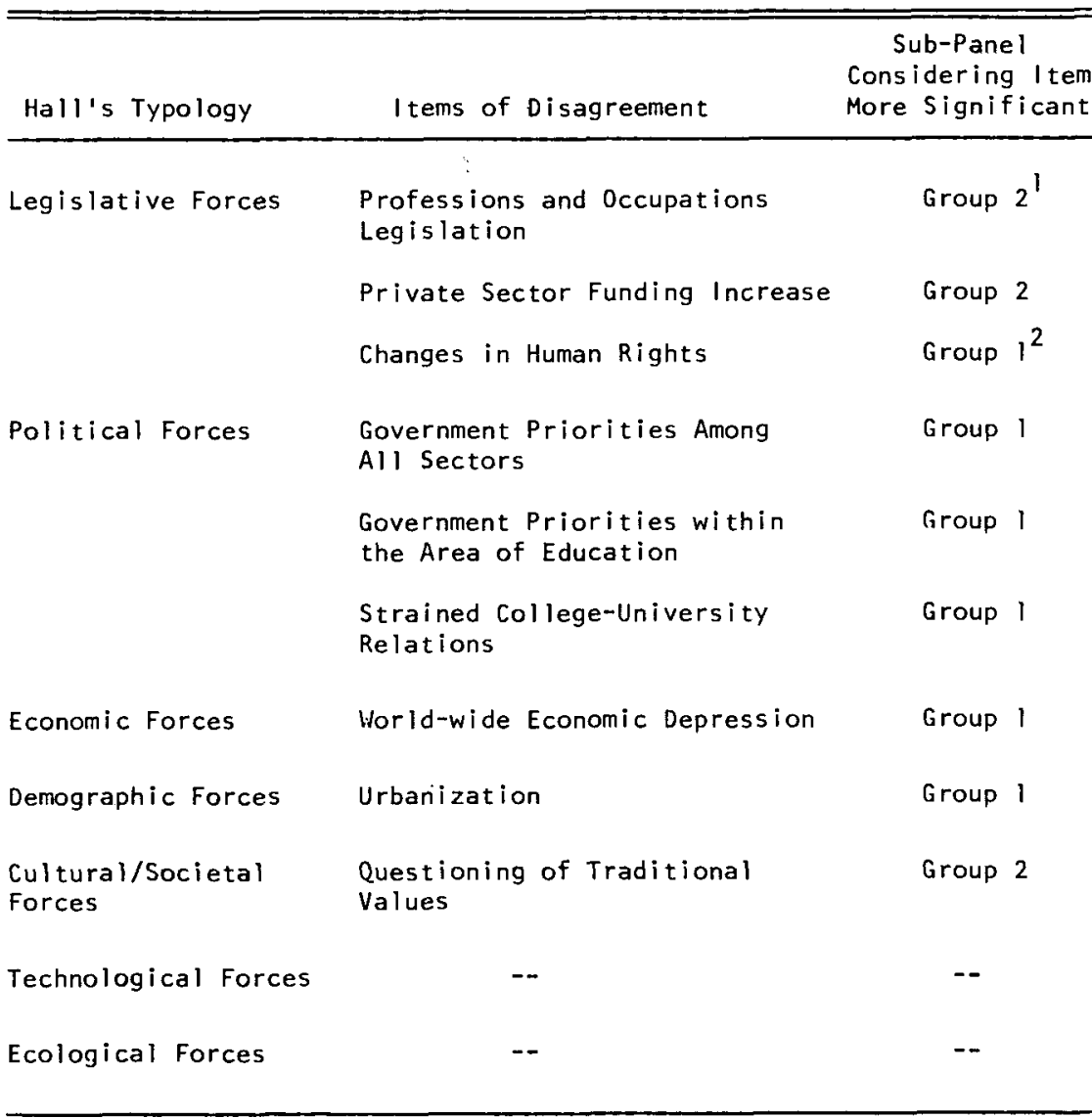

\footnotetext{
Group $2=7$ Alberta Advanced Education and Manpower officials.

${ }^{2}$ Group $1=10$ Alberta community college presidents.
}

College presidents agreed about the importance of all the Political Forces in dispute, namely: Government Priorities Among All Sectors; Government Priorities within the Area of Education; and Strained College-University Relations; while government officials believed that they all were less significant. Government officials agreed that two of the three Legislative Forces were more important, specifically: Professions and Occupations Legislation; and Private Sector Funding Increase; while college presidents viewed Changes in Human Rights Legislation as significant. Presidents also viewed the Economic Force of a World-wide 
Economic Depression and the Demographic Force of Urbanization as important, while government officials believed that the Cultural/Societal Force of Questioning of Traditional Values was significant.

\section{INFLUENCE OF ENVIRONMENTAL FORCES ON TECHNOLOGICAL TRAINING AND RETRAINING}

Round III of the study sharpened the focus on environmental impact by examining the influence of the fifteen other major environmental forces on the sixteenth one, The Demand for Technological Training and Retraining, rated as most significant by respondents. Six forces were rated as influential. These included, in rank order:

1. Intensified Development of the Resource Industry

2. A Growing Alberta Population

3. Industrial Expansion

4. Computer Technology

5. A Government Policy of Fiscal Restraint

6. Decentralization of College Services by Region.

\section{GROUP DIFFERENCES}

As in Round II, the $t$-test was used to determine significant differences at the .05 level between Alberta community college presidents and Advanced Education and Manpower officials. Only one item of the fifteen was significant, namely A Growing Alberta Population (see Table 5). College presidents believed that this force would be more influential on policy development $($ mean $=1.2$ ), while government officials believed it would be somewhat less influential $($ mean $=1.7)$. There was more agreement among the presidents (S.D. $=0.4$ ) than among government officials (S.D. $=0.5$ ). A glance at the frequency of responses for each of the two groups shows a near-perfect reversal of opinions: college presidents generally rated influence as high with only two rating it as moderate, while only two government officials rated it as high, the majority rating it as moderate. It is likely that the disagreement over this force's influence led to the reversal of its rank order with Intensified Development of the Resource Industry from Round II to Round III.

It is interesting to note that the major environmental force which elicited significant disagreement between the two sub-panels in Round II, Government Priorities Among All Sectors, was no longer an item of disagreement when considered in relation to the specific policy decision area of Technological Training and Retraining. 
Group $1=10$ Alberta community college presidents.

${ }^{2}$ Group $2=7$ Alberta Advanced Education and Manpower officials.

Frequency of Responses

Influential Force

Questionnaire

Group

Mean SD

2-Tail

$\begin{array}{lll}2 & 3 & 4\end{array}$

Growing Alberta Population

1

10

1.20 .4

1.70 .5

0.035
8

2 


\section{SUMMARY OF FINDINGS}

In both Rounds II and III one major item of significant difference was identified at the .05 level between Alberta community college presidents and Advanced Education and Manpower officials, although in Round II eight other forces not considered major drew differing responses. In Round II, the Major Environmental Force which elicited differing opinions was Government Priorities Among All Sectors which college presidents felt was more likely and would have greater impact on colleges, while government officials believed it was less likely and would have less impact.

In Round III, the same Major Environmental Force was no longer considered significant when viewed in relation to policy development in the area of Technological Training and Retraining. Instead, however, disagreement arose over another Major Environmental Force from Round II, now considered a Major influential Force on Technological Training and Retraining, specifically, A Growing Alberta Population. Again, this force was deemed more influential by college presidents and less influential by government officials.

\section{CONCLUSION}

Do Alberta's community college presidents and senior government officials share the same perspective? Essentially, the answer is, "Yes, they do." Despite the fact that the presidents are older and have more experience in postsecondary education while the government officials are younger and have less experience but more education, both groups have a similar perception of what the impact of the environment on the colleges is likely to be in the decade of the eighties.

College presidents are more concerned about the Alberta government's ranking of the needs of postsecondary education in relation to other sectors in the province than are government officials. There are two possible explanations for this difference in view. One is that the government officials have a better understanding of the methods employed by the Cabinet in fund allocation. The other, less happy, explanation is that the government officials are too entrenched in their bureaucracy to believe that funds could be seriously cut back.

At any rate, when the force Government Priorities Among All Sectors is seen in relation to The Demand for Technological Training and Retraining, no disagreement exists. It is apparent to both groups that this is an area of major concern to the government of Alberta and that therefore funds are likely to continue to be available for related development.

The presidents also see the force, A Growing Alberta Population, as having greater influence on Technological Training and Retraining than government officials do. The difference in perspective may be related to geographic location. The presidents are dispersed among the various regions of the province and view regional growth more immediately than do the government officials located in Edmonton. Their colleges may already be experiencing strain in keeping up with public demands. On the other hand, the Alberta government officials may 
have a clearer grasp of department plans to meet the needs of this growing population on a province-wide basis and therefore view the impact of this force as being less of a problem.

Overall, it can be generalized that there was agreement between the two sub-panels of Alberta community college presidents and Alberta Advanced Education and Manpower officials in their perspective regarding the influence of environmental forces on the development of Alberta's community colleges in the 1980's. Disagreement only occurred over two of the sixteen major environmental forces identified in the study.

\section{IMPLICATIONS}

The implications of these findings are positive for college-government relations. A similar perception about environmental pressures likely to be experienced by postsecondary institutions in the eighties should facilitate the planning and budgeting processes. As a major portion of the college dollar will continue to come from government, good communication is essential.

One might ask the question then, why does the impression exist that communication between government and the colleges is less than satisfactory, that a "we-they" stance is common? One possible explanation is that weak communication links occur within each group rather than between the two groups. For example, college members presenting a proposal to government for funding may not be adequately briefed on the best method of presentation, where current funding priorities lie, or how to provide alternatives for reaction. On the other hand, members of government may not have sufficient information about a specific college's overall financial situation, program capabilities, or local needs in order to react appropriately.

The results of this study would seem to indicate that the environmental perception shared by senior members of both government and the colleges should be communicated internally to other staff members. A broader base of understanding about environmental factors should strengthen the institutions' ability to cope with rapid change.

\section{REFERENCES}

Barrington, Gail Vallance. The Impact of Environmental Forces on Alberta Community Colleges 1980.1990. Unpublished doctoral dissertation, Department of Educational Administration, University of Alberta, 1981.

Cohen, Arthur M. and March, James G. Leadership and Ambiguity: The American College President. A report prepared for the Carnegie Commission on Higher Education. New York: McGraw-Hill, 1974.

Hall, Richard H. Organizations: Structure and Process. Second edition. Englewood Cliffs: Prentice-Hall, 1977.

Popham, W. James and Sirotnik, Kenneth A. Educational Statistics: Use and Interpretation. Second edition. New York: Harper and Row, 1973. 